\title{
IGF-I, IGFBP-2 and -3 but not GH concentrations are different in normal and poor growing piglets
}

\author{
Roberta SALERI ${ }^{\mathrm{a}}$, Mario BARATTA ${ }^{\mathrm{a}}$, Gian Luca MAINARDI ${ }^{\mathrm{a}}$, \\ Robert RenAVILlE ${ }^{\mathrm{b}}$, Andrea GiUstina ${ }^{\mathrm{c}}$, Fausto QuintaVAlla ${ }^{\mathrm{d}}$, \\ Carlo TAMANINI ${ }^{\mathrm{a} *}$ \\ ${ }^{a}$ Istituto di Fisiologia Veterinaria, Università di Parma, Italy \\ b Département de Biologie Moléculaire et Physiologie Animale, \\ Faculté d'Agronomie, Gembloux, Belgium \\ c Clinica Medica, Università di Brescia, Italy \\ ${ }^{\mathrm{d}}$ Istituto di Clinica Medica Veterinaria, Università di Parma, Italy
}

(Received 23 October 2000; accepted 5 February 2001)

\begin{abstract}
In this study we investigated the somatotropic axis in piglets with evident growth delay. Female Suffolk crossbred piglets ( 30 days old; $N=12$ ) were divided into normal weight $(10 \pm 0.9 \mathrm{~kg})$ and poor growing subjects $(7 \pm 0.5 \mathrm{~kg})$ and bled for growth hormone $(\mathrm{GH})$, Insulin-like growth factor-I (IGF-I), Insulin-like growth factor binding protein 2 and 3 (IGFBP-2 and -3) determination. Basal and induced-GH levels were not different in the groups. Plasma IGF-I concentrations were significantly different $(p<0.001): 101.8 \pm 9.8 \mathrm{ng} \cdot \mathrm{mL}^{-1}$ (normal weight group) and $39.5 \pm 4.0 \mathrm{ng} \cdot \mathrm{mL}^{-1}$ (poor growing group). IGFBP-2 and -3 concentrations were significantly $(p<0.001)$ lower in poor growing than in normal piglets. Piglet weight was positively correlated $(r=0.98, p<0.001)$ with IGF-I and IGFBP-2 or -3 concentrations. Our data indicate that growth rate was not correlated to basal or secretagogue-induced GH secretion.
\end{abstract}

growth hormone / somatotropic axis / insulin-like growth factor I / insulin-like growth factor binding protein / piglet

Résumé - Les concentrations de IGF-I, IGFBP-2 et $\mathbf{- 3}$ sont différentes chez les porcelets normaux et chez les porcelets qui présentent un retard de croissance ; cette différence n'existe pas pour la GH. L'objet de cette étude est l'axe somatotrope chez les porcelets présentant un retard de croissance manifeste. Douze porcelets femelles croisés Suffolk (âgés de 30 jours) ont été subdivisés en deux groupes : sujets de poids normal $(10 \pm 0,9 \mathrm{~kg} ; N=6)$ et sujets avec retard de croissance $(7 \pm 0,5 \mathrm{~kg} ; N=6)$ : des prélèvement sanguins ont été effectués pour la détermination de l'hormone de croissance (GH), de l'Insulin-like growth factor I (IGF-I), et des Insulin-like growth factor binding protein-2 et -3 (IGFBP-2 et -3). Aucune différence n'a été observée entre les concentrations basale et induite

* Correspondence and reprints

E-mail: vetfisio@unipr.it 
de GH des deux groupes, tandis que les concentrations plasmatiques de IGF-I ont présenté une différence significative $(p<0,001): 101,8 \pm 9,8 \mathrm{ng} \cdot \mathrm{mL}^{-1}$ (groupe poids normal) et $39,5 \pm 4,0 \mathrm{ng} \cdot \mathrm{mL}^{-1}$ (groupe retard de croissance). En outre, les concentrations de IGFBP- 2 et -3 ont été significativement inférieures $(p<0,001)$ chez les porcelets en retard de croissance. Le poids des porcelets est positivement corrélé $(r=0,98, p<0,001)$ aux concentrations de IGF-I, IGFBP-2 ou -3. Ces résultats suggèrent donc l'absence d'une corrélation entre niveau de croissance et sécrétion basale ou induite de la GH.

hormone de croissance / axe somatotrope / insulin-like growth factor I / insulin-like growth factor binding protein / porcelet

\section{INTRODUCTION}

Growth hormone $(\mathrm{GH})$ is the main regulator of post-natal growth in mammals; its pulsatile release from anterior pituitary is primarily regulated by two hypothalamic hormones, GH-releasing hormone (GHRH) and somatostatin (SRIH), which play an excitatory and an inhibitory role, respectively. Most of the anabolic GH effects are mediated by IGF-I, which is synthesized and secreted after $\mathrm{GH}$ binds to specific receptors, as well as those of GH itself [29]. Circulating IGF-I is found in association with specific binding proteins (IGFBPs); in particular IGFBP-3 appears to be the main carrier of IGF-I in the adult pig, while IGFBP-2 is the main carrier during fetal life [33]. GH secretion can be modulated by peptides other than GHRH and SRIH, which exert their effects by acting at pituitary and/or hypothalamic level, in particular the new family of synthetic GH-releasing peptides (GHRPs) which stimulate $\mathrm{GH}$ release in both animals and humans through a distinct and complementary action at pituitary and hypothalamic level [5]. GH has been shown to be affected also by galanin [30], which is highly concentrated in the hypothalamus and colocalized with GHRH in median eminence [19]. GHRH, galanin and GHRPs are actively used as provocative tests of $\mathrm{GH}$ release for the diagnosis of $\mathrm{GH}$ deficiency (GHD) in children with short stature and low growth velocity for age and in adults $[1,5]$. Studies on GHD in domestic animals are more limited due to the costs of the diagnostic trials and to the many factors involved in the growth regulation (breed, hormonal and social behaviour, management, etc.), even if these tests may be usefully carried out to investigate the potential availability of pituitary GH. On the other hand, the different growth rates of piglets of the same age is a frequent problem which causes economical losses in pig production. The aim of the present study was to investigate the somatotropic axis function in piglets with evident growth delay 4 weeks after birth: we studied the patterns of $\mathrm{GH}$ secretion, both spontaneous and as stimulated by GHRH, GAL and HEX provocative tests and we determined IGF-I, IGFBP2 and 3 concentrations in plasma during the experimental period.

\section{MATERIALS AND METHODS}

\subsection{Animals}

The experiments were performed from November to February. Female Suffolk crossbred (specific selection between traditional English white breeds and improved Duroc with excellent adaptability to different environments, extremely sturdy and adaptive to different feeding schemes, Universal Mangimi, Pordenone, Italy) piglets (30 days old; $N=12$ ), weaned at 23 days of age and obtained from different litters ( $N=9 ; 11$ piglets per litter) of the same breeding were used; poor growing piglets were equally distributed $(10 \%)$ within the 
litters. Animals were divided into two groups: normal weight subjects $(10 \pm 0.9 \mathrm{~kg}$ at day $30, N=6$ ) or poor growing ( $7 \pm$ $0.5 \mathrm{~kg}$ at day $30 ; N=6$ ) piglets. All subjects had shown a normal weight at birth (normal weight subjects $=1.45 \pm 0.3 \mathrm{~kg}$; poor growing subjects $=1.39 \pm 0.4 \mathrm{~kg}$ ). Since the stress for food and social competition is a typical problem in intensive pig production, piglets were housed in single boxes of the same piggery and were allowed to acclimate for 1 week before the trials. A standard diet (Prestarter T51, Magic s.p.a, Parma, Italy) was provided ad libitum; animals had free access to water. Average daily gain (ADG) during the experimental period was $0.16 \mathrm{~kg} \cdot \mathrm{d}^{-1}$ in normal subjects and $0.11 \mathrm{~kg} \cdot \mathrm{d}^{-1}$ in poor growing piglets. When the piglets were day 34 old, a catheter (Certofix ${ }^{\circledR}$ Mono, B. Braun Milano S.p.A., Milan, Italy) was inserted into an external jugular vein under general anesthesia $\left(\mathrm{O}_{2}\right.$ :halothane, 92:8 v/v); the catheter was kept patent with heparinized $\left(10 \mathrm{IU} \cdot \mathrm{mL}^{-1}\right.$ ) saline flushing every two days. Three days (day 37) before the first test, blood samples $(1 \mathrm{~mL})$ were drawn every 10 min for 6 hours, to determine GH plasma profile and IGF-I, IGFBP-2 and -3 levels. Screening tests to evaluate liver function: bilirubin, AST (aspartate aminotransferase), ALT (alanine aminotransferase), GGT (gamma glutamyltransferase) and proteins (total proteins and albumins) were carried out on a plasma sample from each animal. Animals were fed after the end of each sampling collection.

\subsection{GH provocative tests}

Beginning at day 40, each animal was challenged with three tests applied consecutively in random order at 3-day intervals: (1) GHRH(1-29) (GEREF, Serono, Italy) $1 \mu \mathrm{g} \cdot \mathrm{kg}^{-1}$ e.v. bolus, (2) GAL (endotoxin free porcine, Clinalfa, Italy) $10 \mu \mathrm{g} \cdot \mathrm{kg}^{-1} \mathrm{e} . \mathrm{v}$. bolus and (3) HEX (Lerquin-Mediolanum, Italy) $2 \mu \mathrm{g} \cdot \mathrm{kg}^{-1}$ e.v. bolus. Blood sampling started $1 \mathrm{~h}$ prior to the drugs injection and continued for the following 3 hours; samples were collected every $10 \mathrm{~min}$, blood was centrifuged immediately and plasma was stored at $-20{ }^{\circ} \mathrm{C}$ until GH, IGF-I, IGFBP-2 and -3 determinations.

\subsection{IGF-I, IGFBP-2 and IGFBP-3 analysis}

Plasma concentrations of IGF-I, IGFBP-2 and -3 were determined 1 hour before and 2 hours after $\mathrm{GH}$ provocative tests. Hepatic parameters were determined at the beginning of each experiment.

\subsection{Assays}

Plasma GH determination was performed by a specific homologous double-antibody radioimmunoassay [4] validated in our laboratory; pGH (AFP 10864 B) for iodination and standard curve and anti-pGH antiserum (AFP 10318545) were provided by Dr. A.F. Parlow (Pituitary Hormones and Antisera Center, Harbor-UCLA Medical Center, Torrance, CA, USA). Intra- and interassay coefficients of variation were both less than 5\%; the ED50 and ED90 were 2.06 and $0.7 \mathrm{ng} \cdot \mathrm{mL}^{-1}$, respectively.

Commercial kit was used to measure IGF-I (EIA; OCTEIA IGF-I, Tema Ricerca s.r.l, Bologna, Italy): intra- and interassay coefficients of variation at the dose of $50 \mathrm{ng} \cdot \mathrm{mL}^{-1}$ were $3 \%$ and $7 \%$, respectively. The sensitivity limit of the assay was $1.9 \mathrm{ng} \cdot \mathrm{mL}^{-1}$. IGFBP-2 and -3 determination was performed by a validated western ligand blotting [25]. The method can be summarized as follows: $1 \mu \mathrm{L}$ of sodium dodecyl sulfate (SDS)-denatured plasma was applied to a $40 \mathrm{~g} \cdot \mathrm{L}^{-1}$ stacking gel and subjected to electrophoresis through a $125 \mathrm{~g} \cdot \mathrm{L}^{-1}$ polyacrylamide gel. Prestained ${ }^{14} \mathrm{C}$-labelled molecular mass markers (Amersham International plc, Little Chalfont, UK) were run in parallel lanes. Afterwards, gels 
were soaked in Towbin buffer $(25 \mathrm{mM}$ Tris, 192 mM glycine, pH 8.3, containing 200 mL methanol per L) and proteins were blotted onto nitrocellulose (Hybond-C, Amersham) sheets. Electrophoresis and electrotransfer were performed using the Mini-Protean II system (Bio-Rad, Richmond, CA, USA). Membranes were washed with Tris buffered saline (10 mM Tris-HCl, $140 \mathrm{mM} \mathrm{NaCl}$, pH 7.4) supplemented with Nonidet P-40 (30 g.L ${ }^{-1}$; Sigma, Saint-Louis, M0, USA), then blocked with Tris buffered saline containing bovine serum albumin $\left(10 \mathrm{~g} \cdot \mathrm{L}^{-1}\right.$; RIA grade, Sigma) and finally soaked in Tris buffered saline containing Tween-20 (1 mL $\cdot \mathrm{L}^{-1}$; chemical grade, Fluka Chemie, Buchs, Switzerland). The incubation with ${ }^{125}$ I-recombinant bovine IGF-I ( $40 \times$ $106 \mathrm{cpm} \cdot \mathrm{m}^{-2} \mathrm{blot}$ ) was carried out overnight at $4{ }^{\circ} \mathrm{C}$ in Tris buffered saline containing bovine serum albumin $\left(10 \mathrm{~g} \cdot \mathrm{g}^{-1}\right)$ and Tween $20\left(1 \mathrm{~mL} \cdot \mathrm{L}^{-1} ; 300 \mathrm{~mL} \cdot \mathrm{m}^{-2}\right.$ blot $)$. Thereafter, the membranes were washed twice with Tris buffered saline containing Tween-20 $\left(1 \mathrm{~mL} \cdot \mathrm{L}^{-1}\right)$ and three times in Tris buffered saline. Then they were airdried and exposed to Kodak X-Omat AR films (Koningsloo-Vilvoorde, Belgium) for 2 to 4 days at $-70^{\circ} \mathrm{C}$. Autoradiograms were scanned using scanning densitometry (Sharp JX-325, Pharmacia, Uppsala, Sweden) and band intensities were measured for each lane using the Image Master (Pharmacia). A plasma pool was also used as internal standard to calibrate the different autoradiograms. Optical densities of IGFBP-2 and -3 were measured for each plasma pool on each gel: intra- and interassay coefficients of variation were $9 \%$ and $16 \%$, respectively.

Samples for hepatic screening tests were analysed using the COBAS MIRA PLUS (Roche Diagnostics, Milano, Italy).

\subsection{Data analysis}

The pulsatile patterns of GH secretion were analysed in each individual animal using the PULSAR program [17]. A coefficient of variation of 5\% was used for all points on the standard curve of GH. Exclusion criteria for pulse identification were 3.98, 2.4, 1.7, 1.2 and 0.9 within-assay SD for pulses with a duration of 1, 2, 3, 4 and 5 time points, respectively. In GH- secretagogues challenges a multifactorial ANOVA (Statgraphics Package, STSC Inc., Rockville, MD, USA) was performed (main effect growth class, animal, treatment). The area under the curve (AUC) was calculated using the Sigma Plot 5.0 program (Sigma). Student's $t$ test was used to determine statistical differences when AUCs were compared. IGF-1, IGFBP-2 and -3 data were analyzed by multifactorial ANOVA (main effect growth class and treatment). Student's $t$ test for unpaired data was used to determine statistical differences when IGFBP-2 and -3 were compared. Hepatic data were analyzed by one-way ANOVA (main effect growth class). Regression analyses were performed between weight and IGF-I, IGFBP-2 or -3 according to a linear model: $\mathrm{Y}=\mathrm{a}+\mathrm{b}^{*} \mathrm{X}$, independent variable: weight; dependent variable: IGF-1, IGFBP-2 or -3.

\section{RESULTS}

$\mathrm{GH}$ basal levels in plasma and peak parameters did not differ between normal weight and poor growing piglets: $\mathrm{GH}$ concentrations (mean \pm SEM) were $3.8 \pm 0.1$ and $4.1 \pm 0.2 \mathrm{ng} \cdot \mathrm{mL}^{-1}$, respectively. Representative $\mathrm{GH}$ profiles from one normal and one poor growing subjects are shown in Figure 1. Mean peak height was $9.4 \pm 1.2$ and $8.9 \pm 0.4 \mathrm{ng} \cdot \mathrm{mL}^{-1}$, respectively; mean peak frequency was 0.8 per hour in all animals.

All animals were responsive to $\mathrm{GH}$ provocative tests (Fig. 2): no significant differences were observed between the two body weight groups treated with GHRH, GAL or HEX. AUC (ng. $\mathrm{mL}^{-1}$ per $80 \mathrm{~min}$, mean \pm SEM $)$ in control subjects $(N=6)$ were: $2954.5 \pm 598,1865 \pm 401$ and $3698 \pm$ 305 after GHRH, GAL or HEX stimulation, 


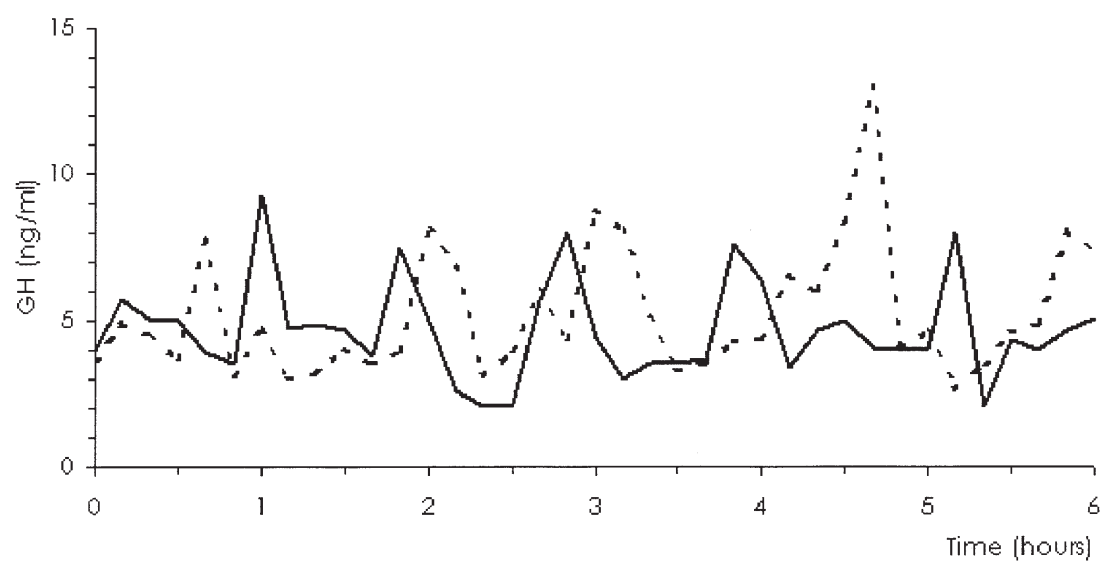

Figure 1. Representative GH plasma profiles in a normal weight (_ $\_$) and in a poor growing (-.---) piglet: both animals reflect the trend of their own group.
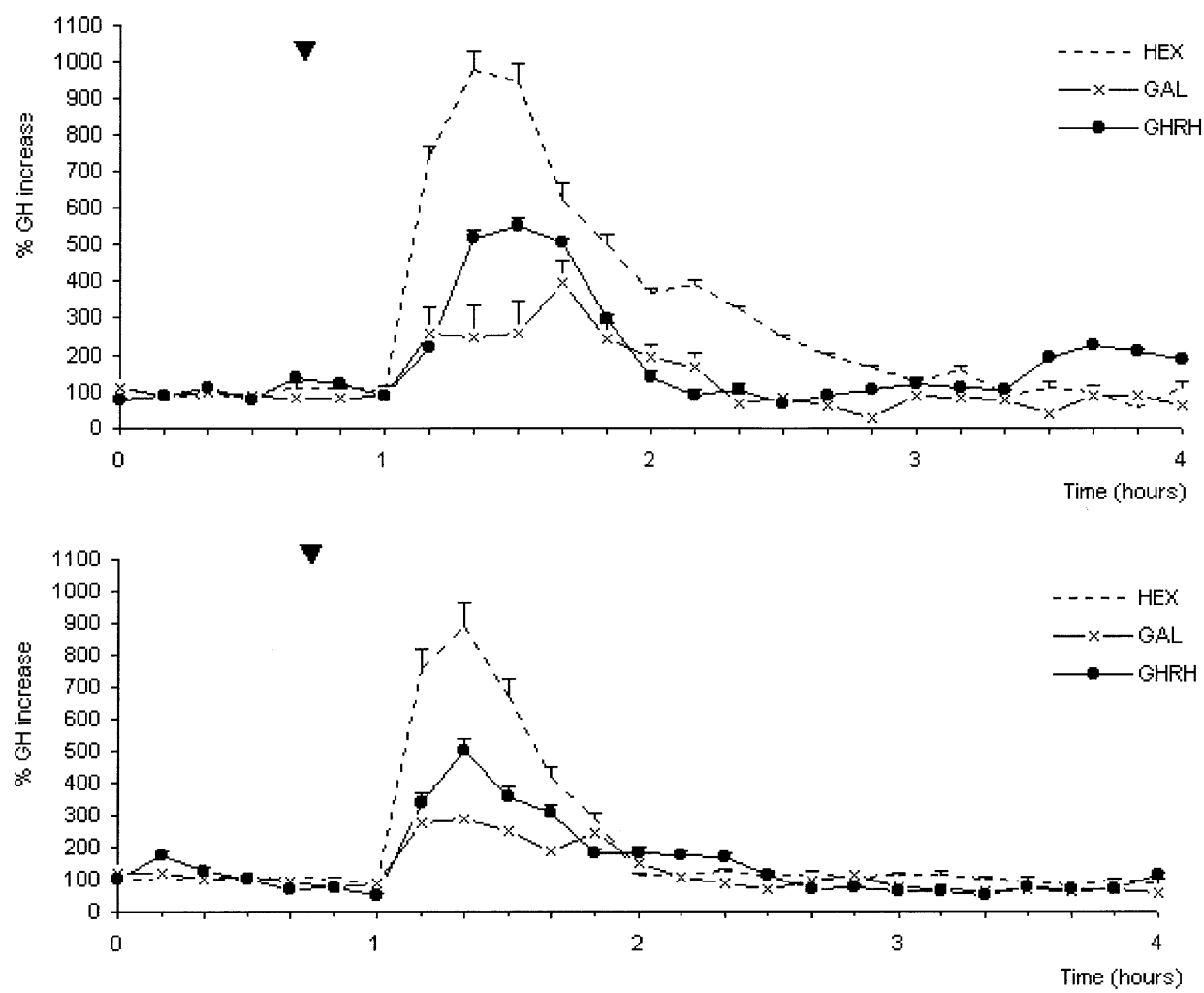

Figure 2. Plasma GH responses (mean $\pm \mathrm{SEM}$ ) to $\mathrm{GH}$ provocative tests (HEX $2 \mu \mathrm{g} \cdot \mathrm{kg}^{-1}$, GAL $10 \mu \mathrm{g} \cdot \mathrm{kg}^{-1}$ and GHRH $1 \mu \mathrm{g} \cdot \mathrm{kg}^{-1}$ e.v. bolus) in normal $(N=6)$ [upper panel] and poor growing $(N=6)$ piglets [bottom panel]. 


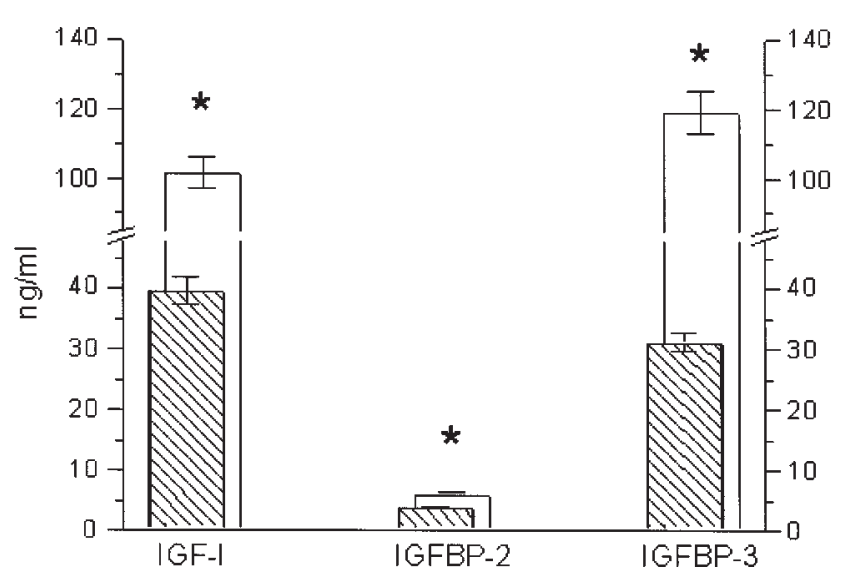

Figure 3. Basal IGF-I, IGFBP-2 and -3 levels (mean \pm SEM) in normal weight animals (open bars; $N=6$ ) and in subjects with growth delay (hatched bars; $N=6$ ). IGFBPs were determined by Western ligand blotting of plasma samples: quantitative results are expressed as arbitrary units as determined by laser densitometric scanning. * indicates values significantly $(p<0.001)$ different. respectively; in poor growing piglets $(N=6)$ AUC were $2248.4 \pm 344,1530.9 \pm 350$ and $3469 \pm 214$ in response to GHRH, GAL and HEX, respectively.

Basal IGF-I concentrations in plasma were $101.8 \pm 9.8 \mathrm{ng} \cdot \mathrm{mL}^{-1}$ in piglets with a normal body weight and $39.5 \pm 4.0 \mathrm{ng} \cdot \mathrm{mL}^{-1}$ $(p<0.001)$ in subjects with evident delay of growth (Fig. 3); IGF-I levels were correlated with the body weight $(p<0.001$, $r=0.98$, standard deviation of the residuals $=1.32$ ). A similar pattern was observed for IGFBP-3, which concentration in poor growing piglets was significantly lower $(p<0.001)$ than in normal weight subjects with high correlation with body weight ( $p<0.001, r=0.88$, standard deviation of the residuals $=32.80)$. Also IGFBP-2 levels were significantly lower $(p<0.001)$ in piglets with growth delay with significant correlation with body weight $(p<0.05$; $r=0.72$, standard deviation of the residuals $=1.32$ ). In both groups IGFBP-3 concentrations were significantly higher than IGFBP-2 ones ( $p<0.01$ ) (Fig. 3). IGF-I, IGFBP-2 and -3 levels were not affected by $\mathrm{GH}$ secretagogues in either group (data not shown)

The hepatic parameters did not show any significant differences between the two groups (Tab. I).

\section{DISCUSSION}

"Poor growing piglet" points out a frequent problem in pig production, that is the presence of animals from the same litter or from different groups after weaning, with growth deficiency: normal weighing subjects at birth ( $\geq 1 \mathrm{~kg}$ ) could show severe growth depression in absence of evident health problems. We performed the present study to investigate whether the growth delay in these animals may be due to an alteration of GH/IGF-I axis. In fact, growth is mainly regulated by $\mathrm{GH}$, but modulated by several endogenous and exogenous factors which may complicate the diagnosis of GHD also in humans. This hypothesis is still controversial; some authors [24] reported that GH deficiency does not appear to explain normally occurring short stature in children and studies using high and /or prolonged dosages of GH do not suggest a problem with limited endogenous $\mathrm{GH}$ in the young pig $[10,16]$. On the other hand, several studies proposed a $\mathrm{GH}$ involvement in cause and therapy of slow growth $[11,18$, $20,23]$. In farm animals the diagnostic trials applied to the identification of GHD are even much more limited by factors like breed, management and social or behavioural stress. Louveau and Bonneau [15], for example, 
Table I. Hepatic parameters in the normal and poor growing piglets ${ }^{\mathrm{a}}$.

\begin{tabular}{|c|c|c|c|c|c|c|}
\hline \multirow{2}{*}{$\begin{array}{l}\text { Liveweight } \\
(\mathrm{kg})\end{array}$} & \multirow{2}{*}{$\begin{array}{c}\text { Bilirubin }\left(\mathrm{mg} \cdot \mathrm{dL}^{-1}\right) \\
(0-0.24)\end{array}$} & \multicolumn{3}{|c|}{ Liver enzymes $\left(\mathrm{U} \cdot \mathrm{L}^{-1}\right)$} & \multicolumn{2}{|c|}{ Protein $\left(\mathrm{g} \cdot \mathrm{L}^{-1}\right)$} \\
\hline & & $\begin{array}{l}\text { GOT } \\
(0-40)\end{array}$ & $\begin{array}{l}\text { GPT } \\
(0-40)\end{array}$ & $\begin{array}{l}\text { GGT } \\
(0-50)\end{array}$ & $\begin{array}{c}\text { Total } \\
(56-85)\end{array}$ & $\begin{array}{c}\text { Albumin } \\
(20-39)\end{array}$ \\
\hline $\begin{array}{l}10 \pm 0.9 \\
\text { (control subjects) }\end{array}$ & $0.1 \pm 0.02$ & $15.1 \pm 1$ & $15.8 \pm 1$ & $15.2 \pm 1$ & $57 \pm 0.6$ & $24 \pm 0.02$ \\
\hline $\begin{array}{l}7 \pm 0.5 \\
\text { (poor growing subjects) }\end{array}$ & $0.083 \pm 0.003$ & $19.2 \pm 2$ & $17.7 \pm 0.6$ & $13.2 \pm 1$ & $60 \pm 0.7$ & $25 \pm 0.03$ \\
\hline
\end{tabular}

a Normal ranges for pig blood are reported in brackets [16].

reported that Large White and Meishan pigs have similar GH levels and hepatic $\mathrm{GH}$ receptors, even if Meishan pigs show greater tissue adipose and lower muscle accretion as compared to Large White breed. IGF-I concentrations are lower in Meishan than in Large White subjects, suggesting a different IGF-I secretion potential in the two breeds. Effects of temperature, feeding and stress on GH and IGF-I levels are also reported $[6,7]$. The provocative tests of GH have been introduced in human medicine to assess the hypothalamic and/or pituitary functional integrity and a whole series of pharmacological stimuli has been used to test $\mathrm{GH}$ secretion [28]. In this study we chose to stimulate GH axis with GHRH, HEX and GAL, at concentrations that induce the maximal response according to our preliminary studies that agree well with data recently reported in prepubertal children [2, 8, 9]. Our results clearly indicate that the growth rate in piglets does not depend on $\mathrm{GH}$ secretory status: in both control and under weight piglets, mean $\mathrm{GH}$ concentration, number and amplitude of peaks were not different. All animals were responsive to GH provocative tests, thus confirming the normal status of pituitary, that is responsive in both intracellular pathways activated by the $\mathrm{GH}$ secretagogues used. In particular, HEX has been shown to induce a GH output significantly higher than that induced by GAL or
GHRH as previously reported [3, 27]; this is obviously due to the different biological potency as well as to the different concentrations of the molecules used. Some authors have hypothesized that the response of GH to SRIF, but not circulating GH levels in neonatal pigs during the last part of pregnancy, is responsible for GH levels after birth [5] and appears to be related to growth rate [31]. However, this observation strictly regards only the last part of pregnancy because an anti-SRIF treatment of neonatal rats does not significantly modify growth rate [26]. Another approach to investigate $\mathrm{GH}$ axis involves the determination of GH-dependent markers. In the last years the common approach was based on IGF-I and IGFBP-3 estimation, in combination with a dynamic GH provocative test. IGF-I and IGFBP-3 levels in pig are low during fetal life and increase during postnatal development [13]; Wester et al. [34] demonstrated that somatotropic axis is functional from birth, even if the sensitivity to GH and IGF-I is low and increases with age [13]. Kraetzl et al. [12] described a positive correlation between IGF-I and growth performance, while Owens et al. [21] reported that $\mathrm{GH}$ levels are unrelated to plasma concentrations of IGF-I. A recent study on transgenic mice where liver IGF-I gene has been knocked-out states that this organ is the main source for circulating IGF-I which may have 
little or no effect on growth; this observation suggests that local production of IGF-I would be the main component responsible for the growth-promoting properties of IGF-I itself [35]. As finally reported by those authors, the role of circulating IGF-I during postnatal growth needs to be elucidated. In our study we observed that IGF-I and IGFBP-3 are correlated to growth performances according to what observed by Owens et al. [22] in pigs aging between 15 and 23 weeks. IGF-I and IGFBP-3 levels in poor growing piglets are remarkable lower than in normal weight animals, whereas no differences are observed in GH secretion parameters. IGFBP-2 levels show a similar trend, but it is interesting to observe that their levels are very low as compared to IGFBP-3 concentration in both groups. In fact, IGFBP-2, the main IGF-I carrier during the foetal life, is replaced by IGFBP-3 during postnatal development [14]. We have reported some hepatic parameters to give more details about liver function: even if the interpretation of the relative changes in specific globulins may be quite difficult, their determination may be helpful in selecting meaningful determinants [32]. It has been also reported in $10 \mathrm{~kg}$-bodyweight piglets that a reduction in serum globulin concentration and an increased AST and total bilirubin concentration from normal range may be interpreted as chronic starvation possibly associated with malabsorption [6]; our data show that the experimental animals did not suffer any kind of starvation. A possible reason of our results is that IGF-I and IGFBP-3 in poor growing piglets may be modulated by an altered responsiveness of hepatic $\mathrm{GH}$ receptors: the delay in growth could reflect a delay in development of the organism in toto and particularly of the liver. Specific investigations on the hepatic receptors or binding proteins are needed to elucidate this problem and to exclude other possible causes (for example, an altered turnover of IGF-I), which may responsible for the growth delay. In conclusion we sug- gest that: (1) peripheral GH levels, as demonstrated in previous studies [8], are not a reliable parameter for growth performance evaluation; (2) poor growing piglets do not present GH deficiency, but low IGF-I, IGFBP-2 and -3 levels and (3) the high correlation between IGF-I and growth performance indicates that IGF-I may be considered a possible convincing indicator for the somatotropic axis status.

\section{ACKNOWLEDGEMENTS}

The authors are indebted to Dr. F. Martini, Istituto di Clinica Chirurgica Veterinaria at Parma's University, for the expert surgical assistance. We thank Mr. Pietro Silva and Dr. Paola Silva, piggery La Badia (Parma), for giving the possibility to organize this study in their piggery.

This work was supported by a FIL grant.

\section{REFERENCES}

[1] Aimaretti G., Baffoni C., Di Vito L., Bellone S., Grottoli S., Maccario V., Arvat E., Camanni F., Ghigo E., Comparisons among old and new provocative tests of $\mathrm{GH}$ secretions in 178 adults, Eur. J. Endocrinol. 142 (2000) 347-352.

[2] Arvat E., Ramunni J., Bellone J., Di Vito L., Baffoni C., Broglio F., Deghenghi R., Bartolotta E., Ghigo E., The GH, prolactin, ACTH and cortisol responses to hexarelin, a synthetic hexapeptide, undergo different age-related variations, Eur. J. Endocrinol. 137 (1997) 635-642.

[3] Arvat E., Maccagno B., Ramunni J., Broglio F., Lanfranco F., Giordano R., Benso A., Deghenghi R., Ghigo E., Influence of galanin and serotonin on the endocrine response to Hexarelin, a synthetic peptidyl GH-secretagogue, in normal women, J. Endocrinol. Invest. 21 (1998) 673-679.

[4] Barb C.R., Estienne M.J., Kraeling R.R., Marple D.N., Rampacek G.B., Rahe C.H., Sartin J.L., Endocrine changes in sows exposed to elevated ambient temperature during lactation, Domest. Anim. Endocrinol. 8 (1991) 117-127.

[5] Bellone J., Bartolotta E., Sgattoni C., Aimaretti G., Arvat E., Bellone S., Deghenghi R., Ghigo E., Hexarelin, a synthetic GH-releasing peptide, is a powerful stimulus of $\mathrm{GH}$ secretion in pubertal and in adults but not in prepubertal children and in elderly subjects, J. Endocrinol. Invest. 21 (1996) 494-500. 
[6] Buonomo F.C., Baile C.A., Influence of nutritional deprivation on insulin-like growth factor I, somatotropin, and metabolic hormones in swine, J. Anim. Sci. 69 (1991) 755-760.

[7] Carroll J.A., Veum T.L., Matteri R.L., Endocrine responses to weaning and changes in post-weaning diet in the young pig, Domest. Anim. Endocrinol. 15 (1998) 183-194.

[8] Cremagnani L., Vaccari M., Maronati E., Cucchi L., Orsatti A., Lazzaroni L., Cantalamessa L., Potentiating effect of galanin on GHRH-induced GH release. Comparison between old and young subjects, Horm. Metab. Res. 28 (1996) 101-104.

[9] Giustina A., Veldhuis D., Pathophysiology of the neuroregulation of growth hormone secretion in experimental animals and human, Endocr. Rev. 19 (1998) 717-797.

[10] Harrel R.J., Thomas M.J., Boyd R.D., Czerwinski S.M., Steele N.C., Bauman D.E., Effect of porcine somatotropin administration in young pigs during the growth phase from 10 to 25 kilograms, J. Anim. Sci. 75 (1997) 3152-3160.

[11] Job J.C., Toublanc J.E., Landier F., Growth of short normal children in puberty treated for 3 years with growth hormone alone or in association with gonadotropin-releasing hormone agonist, Horm. Res. 41 (1994) 177-184.

[12] Kraetzl W.D., Schams D., Brem G., Secretory patterns of porcine growth hormone and insulinlike growth-factor-I in growing pigs, J. Anim. Physiol. Anim. Nutr. 71 (1994) 1-14.

[13] Lee C.Y., Chung C.S., Simmen F.A., Ontogeny of the porcine insulin-like growth factor system, Mol. Cell. Endocrinol. 93 (1993) 71-80.

[14] Liu F., Powell D.R., Styne D.M., Hintz R.L., Insulin-like growth factors (IGFs) and IGF-binding proteins in the developing rhesus monkey, J. Clin. Endocrinol. Metab. 72 (1991) 905-911.

[15] Louveau I., Bonneau M., Effects of a growth hormone infusion on plasma insulin-like growth factor-I in Meishan and Large White pigs, Reprod. Nutr. Dev. 36 (1996) 301-310.

[16] Matteri R.L., Becker B.A., Carrol J.A., Buonomo F.C., Suppression of somatotroph function induced by growth hormone treatment in neonatal pigs, Domest. Anim. Endocrinol. 14 (1997) 109-118.

[17] Merriam G.R., Wachter K.W., Algorithms for the study of episodic hormone secretion, Am. J. Physiol. 243 (1982) E310-E318.

[18] Mitchell H., Dattani M.T., Nanduri V., Hindmarsh P.C., Preece M.A., Brook C.G., Failure of IGF-1 and IGFBP-3 to diagnose growth hormone insufficiency, Arch. Dis. Child. 80 (1999) 442-447.

[19] Niimi M., Takahara J., Sato M., Kawanishi K., Immunohistochemical identification of galanin and growth hormone-releasing factor-containing neurons projecting to the median eminence of the rat, Neuroendocrinology 51 (1990) 572-575.
[20] Ogilvy-Stuart A.L., Hands S.J., Adcock C.J., Holly J.M.P., Matthews D.R., Mohamed-Ali V., Yudkin J.S., Wilkinson A.R., Dunger D.B., Insulin, insulin-like growth factor I (IGF-I), IGF-binding protein-I, growth hormone, and feeding in the newborn, J. Clin. Endocrinol. Metab. 83 (1998) 3550-3557.

[21] Owens P.C., Conlon M.A., Campbell R.G., Johnson R.J., King R., Ballard F.J., Developmental changes in growth hormone, insulin-like growth factors (IGF-I and IGF-II) and IGF-binding proteins in plasma of young growing pigs, J. Endocrinol. 128 (1991) 439-447.

[22] Owens P.C., Gatford L., Walton P.E., Morley W., Campbell R.G., The relationship between endogenous insulin-like growth factors and growth in pigs, J. Anim. Sci. 77 (1999) 2098-2103.

[23] Pasquino A.M., Municchi G., Pucarelli I., Segni M., Mancini M.A., Troiani S., Combined treatment with gonadotropin-releasing hormone ana$\log$ and growth hormone in central precocious puberty, J. Clin. Endocrinol. Metab. 81 (1996) 948-951.

[24] Pozo J., Argente J., Barrios V., Gonzales-Parra S., Munoz M.T., Hernandez H., Growth hormone secretion in children with normal variants of short stature, Horm. Res. 41 (1994) 185-192.

[25] Renaville R., Devolder A., Massart S., Sneyers M., Burny A., Portetelle D., Changes in the hypophyso-gonadal axis during the onset of puberty in young bull calves, J. Reprod. Fertil. 99 (1993) 443-449.

[26] Robinson G.M., Spencer G.S., Berry C.J., Dobbie P.M., Hodgkinson S.C., Bass J.J., Evidence of a role for growth hormone, but not for insulin-like growth factors-I or II in the growth of the neonatal rat, Biol. Neonat. 64 (1993) 158-165.

[27] Sacchi M., Pincelli A.I., Cavagnini F., Growth hormone in obesity, Int. J. Obes. Relat. Metab. Disord. 23 (1999) 260-271.

[28] Shalet S.M., Toogood A., Rahim A., Brennan B.M.D., The diagnosis of growth hormone deficiency in children and adults, Endocr. Rev. 19 (1998) 203-223.

[29] Spencer G.S.G., Hallett K.G., Beermann U., MacDonald A.A., Changes in the levels of growth hormones, insulin, cortisol, thyroxine and somatomedin-C/IGF-1, with increasing gestational age in the fetal pig, and the effect of thyroidectomy in utero, Comp. Biochem. Physiol. A 93 (1989) 467-472.

[30] Tatemoto K., Rokaeus A., Jornvall H., McDonald T., Mutt V., Galanin - a novel biologically active peptide from porcine intestine, FEBS Lett. 164 (1983) 124-128. 
[31] Torronteras R., Gracia-Navarro F., Elsaesser F. Different effects of somatostatin on in vitro growth hormone release in two porcine breeds with different growth rates, J. Neuroendocrinol. 8 (1996) 891-900.

[32] Tumleson G., Schmidt F., Scholl D., Hematology and Clinical Chemistry, in: Leman A.D., Straw B., Mengeling W.L., Penny R.H.C., Scholl E. (Eds.), Diseases of swine, VI ed, Iowa State University Press, Ames, Iowa, USA, 1986, pp. 35-39.

[33] Walton P.E., Etherton T.D., Effects of porcine growth hormone and insulin-like growth factor
(IGF-I) on immunoreactive IGF-binding protein concentration in pigs, J. Endocrinol. 120 (1989) 153-160.

[34] Wester T.J., Davis T.A., Fiorotto M.L., Burrin D.G., Exogenous growth hormone stimulates somatotropic axis function and growth in neonatal pigs, Am. J. Physiol. 274 (1998) E29-E37.

[35] Yakar S., Liu J.L., Stannard B., Butler A., Accili D., Sauer B., LeRoith D., Normal growth and development in the absence of hepatic insulinlike growth factor I, Proc. Natl. Acad. Sci. USA 96 (1999) 7324-7329. 